\title{
$M u$-Opioid receptors modulate noradrenaline release from the rat hippocampus as measured by brain microdialysis
}

\author{
Machiko Matsumoto ${ }^{\mathrm{a}, *}$, Mitsuhiro Yoshioka ${ }^{\text {a }}$, Hiroko Togashi ${ }^{\text {a }}$, Mitsugu Hirokami ${ }^{\text {a }}$, \\ Masahiro Tochihara ${ }^{\mathrm{a}}$, Toshiya Ikeda ${ }^{\mathrm{a}}$, Charles B. Smith ${ }^{\mathrm{b}}$, Hideya Saito ${ }^{\mathrm{a}}$ \\ ${ }^{a}$ First Department of Pharmacology, Hokkaido University School of Medicine, Kita-15, Nishi-7, Kita-ku, Sapporo 060, Japan \\ ${ }^{b}$ Department of Pharmacology, University of Michigan Medical School, Ann Arbor, MI 48109-0626, USA
}

(Accepted 14 September 1993)

\begin{abstract}
The modulation of noradrenaline (NA) release via presynaptic opioid receptors in the hippocampus of freely moving rats was studied by the use of brain microdialysis. Extracellular levels of NA were estimated by assaying its concentrations in the perfusion fluid using high-performance liquid chromatography (HPLC) with electrochemical detection (ECD). Spontaneous NA levels were reduced by tetrodotoxin $(1 \mu \mathrm{M})$ co-perfusion and were increased by peripheral administration of desipramine ( 5 and $10 \mathrm{mg} / \mathrm{kg}$, i.p.). Addition of potassium $\left(\mathrm{K}^{+}, 60\right.$ and $\left.120 \mathrm{mM}\right)$ to the perfusion fluid evoked a concentration-dependent release of NA. $\mathrm{K}^{+}(120 \mathrm{mM})$-evoked NA release was markedly reduced by removal of calcium $\left(\mathrm{Ca}^{2+}\right)$ from the perfusion fluid. These results indicate that both the spontaneous and the $\mathrm{K}^{+}$-evoked NA release measured by the use of brain microdialysis coupled with HPLC-ECD can be used as indices of neuronal release from the noradrenergic nerve terminals. A $\mu$-opioid receptor agonist, morphine $(0.01-10 \mu \mathrm{M})$, when co-perfused with $\mathrm{K}^{+}(120 \mathrm{mM})$, produced a reduction of $\mathrm{K}^{+}$-evoked NA release in a concentration-dependent manner. Neither co-perfusion with a high concentration of [D-Pen ${ }^{2}, D_{-}-P^{5} n^{5}$ ]-enkephalin (DPDPE) (10 $\mu \mathrm{M})$, an agonist selective for $\delta$-opioid receptors, nor with $\mathrm{U}$-69593 $(10 \mu \mathrm{M})$, an agonist selective for $\kappa$-opioid receptors, modified the $\mathrm{K}^{+}(120 \mathrm{mM})$-evoked release of NA. Morphine-induced $(1 \mu \mathrm{M})$ inhibition of NA release was blocked by a $\mu$-opioid receptor antagonist, naltrexone ( 3 and $9 \mathrm{mg} / \mathrm{kg}$, i.p). Naltrexone by itself did not alter the spontaneous NA levels or the $\mathrm{K}^{+}$-evoked NA release. The morphine-induced $(1 \mu \mathrm{M})$ inhibition of NA release was abolished by pretreatment with pertussis toxin (PTX) that was perfused into the hippocampus by push-pull cannulation. These findings suggest that NA release is functionally modulated via the $\mu$-opioid receptors located on noradrenergic nerve terminals in the rat hippocampus. It indicates, furthermore, the possibility that the inhibition of NA release via the $\mu$-opioid receptors is linked to G-proteins which are substrates of PTX.
\end{abstract}

Key words: Noradrenaline; Morphine; Rat hippocampus; Brain microdialysis

\section{Introduction}

It has been well established that at least three distinct types of opioid receptors, $\mu$-, $\delta$ - and $\kappa$-opioid receptors, are present in the rat brain [6,19]. Numerous studies have shown that opioids and opiate alkaloids such as morphine act at the presynaptic nerve terminals to modulate the release of several neurotransmitters. For instance, electrically stimulated $\left[{ }^{3} \mathrm{H}\right] \mathrm{dopa}-$ mine release in the rat striatum was regulated by the $\delta$-opioid receptors [20], while neuronal release of $\left[{ }^{14} \mathrm{C}\right]$

\footnotetext{
* Corresponding author. Fax: (81) (11) 717-1138.
}

acetylcholine in the rat striatum [22] and hippocampus [13] was modulated by inhibitory $\kappa$-opioid receptors. Recently, we have shown that the $\mu$-opioid receptors modulate the physiological release of serotonin (5-HT) from the nerve terminals in the rat hippocampus [34]. These results showed that specific opioid receptors appear to modulate the release of specific neurotransmitter substances in the central nervous system.

Despite an abundance of substantial evidence that central noradrenergic neurons are involved in opiatemodified function, i.e., opiate dependence or withdrawal $[3,7,25,29,32]$, there are few reports concerning the presence and the characteristics of the modulation of opioids on noradrenaline (NA) release in vivo. In vitro studies using rat cortical [21], hypothalamic [10,31] 
and hippocampal slices $[14,16]$ have shown that the noradrenergic nerve terminals are endowed with inhibitory $\mu$-opioid receptors. However, Heijna et al. [11], using rat mediobasal hypothalamic slices, have shown evidence that opioid receptors do not modulate the central noradrenergic nerve activity. Several in vivo studies, on the other hand, showed that the NA turnover in various rat brain regions was increased by acute or chronic administration of morphine [27,30]. In contrast, Gomes et al. [9] reported that acutely administered morphine decreased NA turnover both in the cortex and the brainstem of anesthetized rats. Gabriel et al. [8] reported that NA metabolism in the rat preoptic area-anterior hypothalamus was not altered by the chronic administration of morphine. Therefore, the physiological and functional modulation of opioid receptors on the noradrenergic neurons remains unclear at this time.

A variety of in vivo techniques have been developed to measure the release of neurotransmitters. Brain microdialysis has been established as a useful technique to monitor the changes of neurotransmitters from specific brain areas of freely moving animals. Previous brain microdialysis techniques mostly were carried out to measure NA concentrations in the dialysate by radioenzymatic assay $[5,15,17]$ or the alumina-extracted method $[4,12]$ because of the extremely low concentrations. We have directly measured NA concentrations in the dialysate by using a simple and highly sensitive method, brain microdialysis coupled with high performance liquid chromatography (HPLC) with electrochemical detection (ECD).

The aim of the present study was to characterize the opioid receptors modulating NA release from the nerve terminals in the hippocampus of freely moving rats. Three main focuses of our study were the following: (1) in order to evaluate the validity of extracelluar NA levels as a marker for neuronal release, pharmacological treatments were carried out. (2) Three opioid receptor agonists, morphine $(\mu-)$, DPDPE $(\delta$-) and U$69593(\kappa$-) and a $\mu$-opioid receptor antagonist, naltrexone, were administered to clarify opioid receptor functions. (3) Pertussis toxin (PTX) to inactivate G-proteins-treated rats were used to investigate whether opioid receptor-mediated NA release requires the interaction between opioid receptors and PTX-sensitive G-proteins.

\section{Materials and methods}

\subsection{Animals}

Eight- to 12-week-old male Wistar rats $(250-350 \mathrm{~g})$ were used. Rats were housed in a room with a 12-h light (07.00-19.00)-dark $(19.00-07.00)$ cycle and were given free access to food and water.

\subsection{Brain microdialysis}

A guide cannula was stereotaxically implanted into the hippocampus (rostral-caudal, $-5.8 \mathrm{~mm}$; lateral, $-4.8 \mathrm{~mm}$; ventral, $-4.0 \mathrm{~mm}$, from the bregma and the dural surface) under ketamine $(100 \mathrm{mg} / \mathrm{kg}$, i.p.) anesthesia. Two days after the surgery, a 3-mm concentric dialysis probe was inserted into the hippocampus (ventral, $-7.0 \mathrm{~mm}$ from the dural surface) through the guide cannula and perfused continuously $(2 \mu \mathrm{l} / \mathrm{min})$ with Ringer's solution. In preliminary experiments, the levels of NA in the dialysate were observed to be high immediately after insertion of the probe, but they decreased to a constant value within $100 \mathrm{~min}$. In subsequent experiments, therefore, sampling was started $100 \mathrm{~min}$ after the implantation of the probe. In all experiments, successive $40 \mu \mathrm{l}$ samples were collected at 20 -min intervals in vials containing $10 \mu \mathrm{l}$ of $0.05 \mathrm{~N}$ ice-cold acetic acid and injected directly into the HPLC. At the end of each experiment, the precise insertion site of the dialysis probe was examined histologically.

\subsection{Experimental protocol}

To stimulate $\mathrm{NA}$ release, $\mathrm{KCl}(60 \mathrm{mM}$ or $120 \mathrm{mM})$ was added through the perfusion system during two 10 -min periods. The first addition of $\mathrm{KCl}$ (first stimulation, $\mathrm{S}_{1}$ ) and the second addition of $\mathrm{KCl}$ (second stimulation, $S_{2}$ ) occurred at the beginning of the fourth and the seventh $\left(S_{2}\right)$ collection periods, respectively. Opioid receptor agonists were added to the perfusion fluid at the time of the second addition of $\mathrm{KCl}\left(\mathrm{S}_{2}\right)$. A $\mu$-opioid receptor antagonist, naltrexone, was injected intraperitoneally (i.p.) $20 \mathrm{~min}$ prior to the second $\mathrm{KCl}$-perfusion period $\left(\mathrm{S}_{2}\right)$.

\subsection{Determination of NA concentrations in the dialysate}

Extracellular NA concentrations were assayed by HPLC-ECD immediately after sampling. The HPLC-ECD system consists of a pump (P-500, Irika Kogyo, Kyoto, Japan) coupled to a reversed-phase column (CA-50DS, ODS, $5 \mu \mathrm{m}$ particle size, Eicom Co., Ltd., Kyoto, Japan) and an ECD (E-502, Irika) attached with a Signal Cleaner (SC77, Sic Co., Ltd., Tokyo, Japan). A graphite working electrode (WE-3G, Eicom) was maintained at $450 \mathrm{mV}$ vs. an $\mathrm{Ag} / \mathrm{AgCl}$ reference electrode. The mobile phase, consisting of $0.1 \mathrm{M}$ disodium hydrogenphospate, $0.15 \mathrm{mM}$ EDTA-2Na and $1.85 \mathrm{mM}$ 1-octanesulfonic acid sodium salt, was adjusted to $\mathrm{pH} 6.0$ with $0.1 \mathrm{M}$ sodium hydrogenphospate. Depending on column conditions, 4-6\% (v/v) methanol was added to this solution.

\subsection{Pertussis toxin $(P T X)$ treatment}

PTX treatment was carried out by push-pull perfusion. PTX (1 $\mu \mathrm{g} / \mathrm{ml}$ ) was perfused continuously $(7 \mu \mathrm{l} / \mathrm{min})$ for $70 \mathrm{~min}$ through a push-pull cannula which was inserted into the hippocampus. After perfusion, the push-pull cannula was removed and a microdialysis probe was inserted into the hippocampus. Experiments were carried out as described above.

\subsection{Drugs}

Desipramine hydrochloride (Sigma Chemical Co. Ltd., St. Louis, MO, USA), tetrodotoxin (TTX) (Sigma), pertussis toxin (PTX) (Research Biochemicals Inc., Natic, MA, USA), morphine sulphate (Takeda Pharmaceutical Co. Osaka, Japan), [D-Pen ${ }^{2}$, D-Pen ${ }^{5}$-enkephalin (Sigma), U-69593 (Upjohn Co., Kalamazoo, MI, USA) and naltrexone hydrochloride (DuPont Pharmaceuticals, Garden City, NY, USA). 


\subsection{Calculations and statistical analysis}

NA levels were expressed as a percentage of the absolute amount of NA in the dialysate collected (without correction for recovery) during the third 20-minute collection period, the period immediately before the addition of $\mathrm{KCl}\left(\mathrm{S}_{1}\right)$ to the perfusate. To evaluate the effects of opioid receptor agonists on NA release, the quotient $\left(S_{2} / S_{1}\right)$ was calculated to quantify the ratio of fractional release between the second $\left(S_{2}\right)$ and the first $\left(S_{1}\right)$ periods of stimulation. All results are given as means \pm S.E.M. Statistical comparisons were carried out using analysis of variance followed by Student's $t$-test. Values of $P$ less than $5 \%$ were considered significant.

\section{Results}

\subsection{In vitro experiment}

In order to determine the recovery efficiency of the probe membranes, in vitro recoveries (ratio between the concentration in the perfusate and the concentration outside the dialysis membrane) for some microdialysis probes were measured. Probes were placed in Ringer's solution that contained $10 \mathrm{pg} / \mu 1$ of NA and perfused at a flow rate of $2 \mu \mathrm{l} / \mathrm{min}$ at $37 \pm 1^{\circ} \mathrm{C}$. Mean in vitro recoveries of NA across the dialysis membrane were $8.8 \pm 0.8 \%$ ( $n=7$ probes). The calibration for known amounts of NA which were added to the perfused sample was examined. Good linearity of the response curves of NA was obtained over a range of 10 to $100 \mathrm{pg}$ (data not shown). The detection limits (signal to noise ratio was 3 ) for NA was $0.3 \mathrm{pg}$.

\subsection{Extracellular NA levels}

The basal levels of extracellular NA ranged from 13.8 to $17.9 \mathrm{fmol} / 40 \mu \mathrm{l}$ of dialysate in non-treated control rats. In order to characterize whether extracellular NA levels reflect noradrenergic neuronal activity, we examined the effect of a blocker of sodium channels, TTX. The NA levels were reduced to below the detection limit by the addition of TTX $(1 \mu \mathrm{M})$ to the perfusion fluid for $60 \mathrm{~min}$. NA levels gradually recovered after the removal of TTX from the perfusion fluid (Fig. 1). In addition, peripheral administration of a NA reuptake inhibitor, desipramine, at $5 \mathrm{mg} / \mathrm{kg}$ and 10 $\mathrm{mg} / \mathrm{kg}$ (i.p.) produced significant and dose-dependent increases in NA levels. This stimulating effect of desipramine on NA concentrations was observed up to $180 \mathrm{~min}$ after its administration (Fig. 2).

\subsection{Effect of potassium $\left(K^{+}\right)$stimulation}

In this experiment, high $\mathrm{K}^{+}$concentrations were used to stimulate the release of NA. First we examined the effects of removing calcium $\left(\mathrm{Ca}^{2+}\right)$ from the perfusion fluid on the $\mathrm{K}^{+}$-evoked $\mathrm{NA}$ release. $\mathrm{K}^{+}(120 \mathrm{mM})$

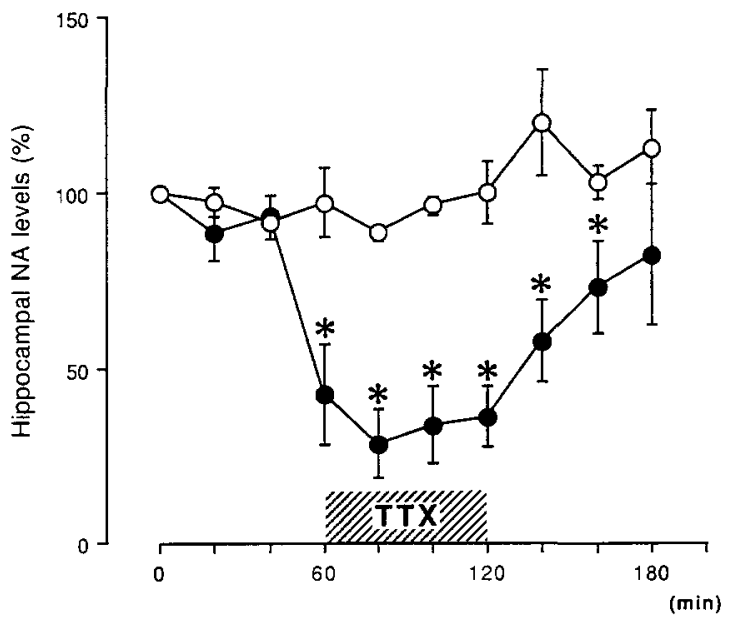

Fig. 1. Effect of a $60 \mathrm{~min}$ perfusion with tetrodotoxin (TTX) $(1 \mu \mathrm{M})$ on extracellular noradrenaline (NA) levels in the rat hippocampus. Each point represents the mean of 5 experiments. Vertical bars represent the S.E.M. Open circles, controls; solid circles, TTX perfused rats. ${ }^{*} P<0.05$ as compared with controls.

added to the perfusion fluid elicited remarkable increases in NA levels. After perfusion with the $\mathrm{Ca}^{2+}$ free, i.e., $4.5 \mathrm{mM}$ EDTA-2Na containing Ringer's solution instead of $\mathrm{Ca}^{2+}$, the $\mathrm{K}^{+}(120 \mathrm{mM})$-evoked NA release was completely prevented. Replacement of the $\mathrm{Ca}^{2+}$-free perfusion fluid with normal Ringer's solution restored the ability to elicit NA release by $\mathrm{K}^{+}(120$ $\mathrm{mM}$ ) stimulation (Fig. 3). As shown in Fig. $4, \mathrm{~K}^{+}(60$ and $120 \mathrm{mM}$ )-stimulation induced significant and concentration-dependent increases in NA concentrations. Sixty $\mathrm{mM} \mathrm{K}^{+}$elicited 6.4 -fold increases in NA release and the mean $\mathrm{S}_{2} / \mathrm{S}_{1}$ ratio was $0.9 \pm 0.1(n=4)$. The increase in NA with $120 \mathrm{mM} \mathrm{KCl}$ was 14.0 -fold over the basal levels during $S_{1}$ and the mean $S_{2} / S_{1}$ ratio was $1.0 \pm 0.1(n=4)$. The mean basal levels of NA

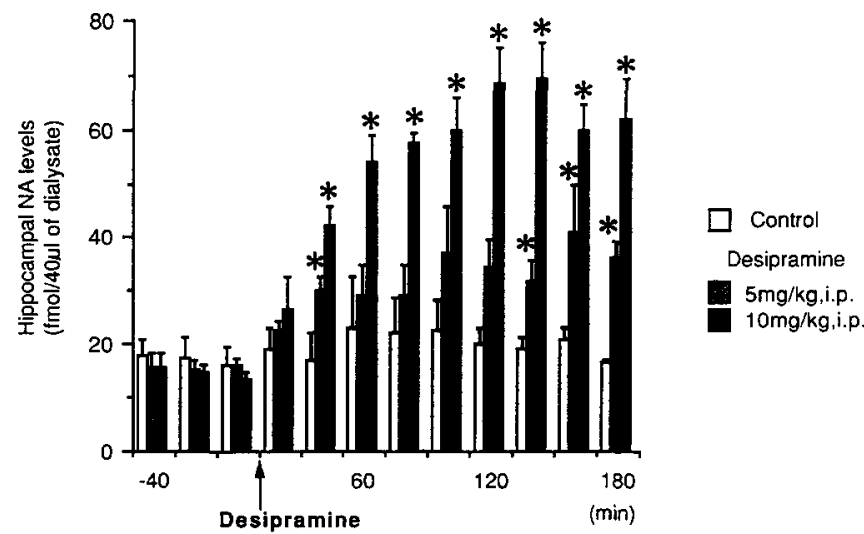

Fig. 2. Effect of intraperitoneal (i.p.) administration of desipramine ( 5 and $10 \mathrm{mg} / \mathrm{kg}$ ) on extracellular noradrenaline (NA) levels in the rat hippocampus. Each point represents the mean of 4-5 experiments. Vertical bars represent the S.E.M. ${ }^{*} P<0.05$ as compared with the saline $(2.5 \mathrm{ml} / \mathrm{kg}$, i.p. $)$ treated controls. 


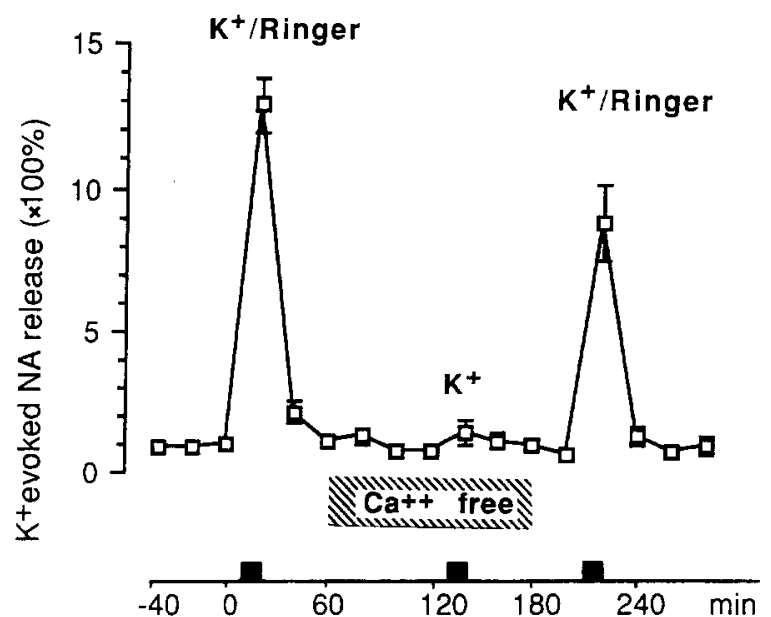

Fig. 3. Effect of calcium $\left(\mathrm{Ca}^{2+}\right)$ omission on the $\mathrm{K}^{+}$-evoked noradrenaline (NA) release in the rat hippocampus. $\mathrm{KCl}\left(\mathrm{K}^{+}\right)(120 \mathrm{mM})$ was perfused for $10 \mathrm{~min}$ periods in the presence (normal Ringer's solution) or absence of $\mathrm{Ca}^{2+}\left(\mathrm{Ca}^{2+}\right.$ free perfusion fluid). In the absence of $\mathrm{Ca}^{2+}, 4.5 \mathrm{mM}$ EDTA-2Na was added to the perfusion fluid instead of $\mathrm{Ca}^{2+}$. Each point represents the mean of 4 experiments. Vertical bars represent the S.E.M.

prior to $\mathrm{K}^{+}(60$ and $120 \mathrm{mM})$ stimulation were $14.1 \pm$ 2.4 and $15.1 \pm 1.7 \mathrm{fmol} / 40 \mu \mathrm{l}$ of dialysate, respectively. In this study, a high $\mathrm{K}^{+}$concentration $(120 \mathrm{mM})$ was used to induce neuronal depolarization because the ratio $S_{2} / S_{1}$ for NA was near unity, i.e., the release of NA induced by $\mathrm{K}^{+}(120 \mathrm{mM})$ was highly reproducible.

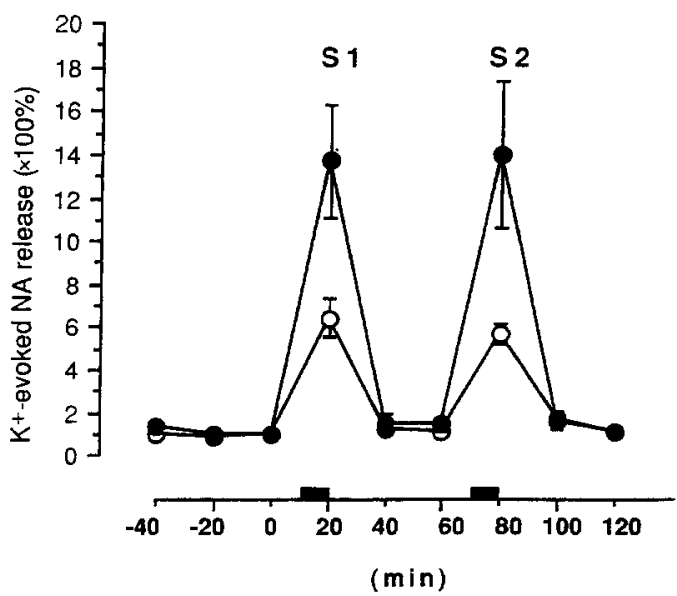

Fig. 4. Effect of $\mathrm{KCl}\left(\mathrm{K}^{+}\right)(60$ and $120 \mathrm{mM})$ on extracellular noradrenaline (NA) levels in the rat hippocampus. $\mathrm{KCl}$ was introduced into the perfusion fluid for 10 -min periods at the fourth $\left(\mathrm{S}_{1}\right)$ and seventh $\left(S_{2}\right)$ periods. NA concentrations are expressed as the' percent of that in the third collection period, i.e., the period immediately before the first administration of $\mathrm{KCl}\left(\mathrm{S}_{1}\right)$. Open circles, 60 $\mathrm{mM} \mathrm{KCl}$; solid circles, $120 \mathrm{mM} \mathrm{KCl}$. Each point represents the mean of 4 experiments. Vertical bars represent the S.E.M.

\subsection{Effect of opioid agonists on $K^{+}$-evoked $N A$ release}

Morphine, a $\mu$-opioid receptor agonist, inhibited dose-dependently the $\mathrm{K}^{+}(120 \mathrm{mM})$-evoked release of NA when added to the perfusion fluid simultaneously with the second stimulation with $\mathrm{KCl}\left(\mathrm{S}_{2}\right)$. Typical chromatograms were obtained from the samples of
(A)

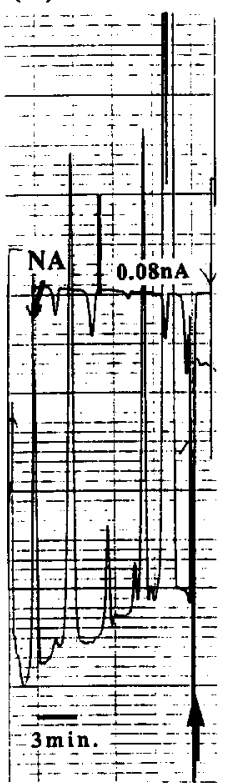

inj. $4 \mu 1$.
(B)

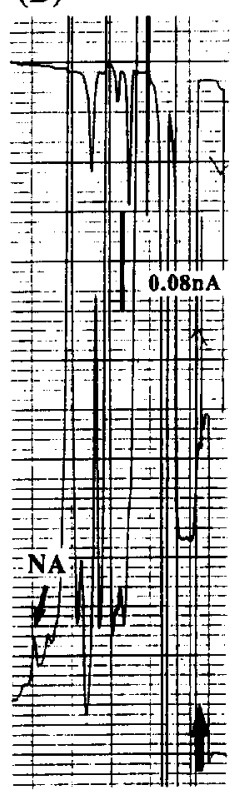

inj. $45 \mu 1$
(C)

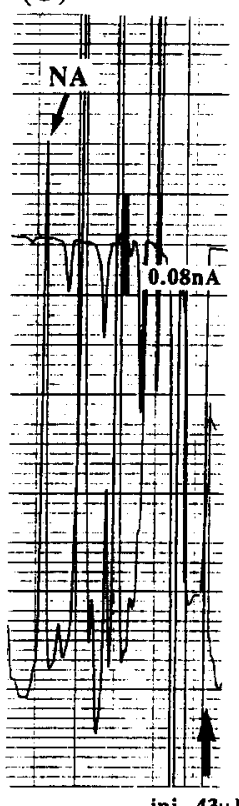

(D)

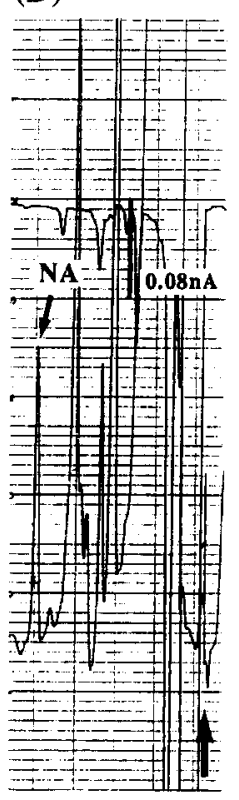

Fig. 5. Chromatograms of (A) a standard of noradrenaline (NA) (20 pg) and the rat hippocampus dialysate perfused with Ringer's solution, (B) under the basal conditions, $(C)$ after $\mathrm{K}^{+}(120 \mathrm{mM})$ stimulation $\left(S_{t}\right)$ and $(D)$ after $\mathrm{K}^{+}(120 \mathrm{mM})$ stimulation in the presence of morphine $(1 \mu \mathrm{M})$ $\left(\mathrm{S}_{2}\right)$. 


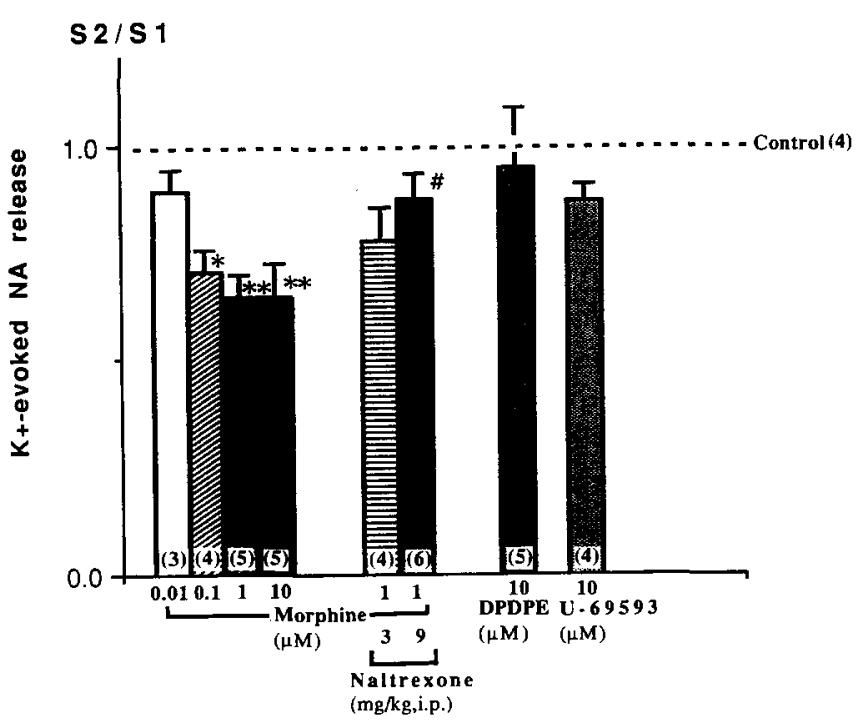

Fig. 6. Effect of opioid agonists and antagonist on $\mathrm{K}^{+}$-evoked noradrenaline (NA) release from the rat hippocampus. Morphine (0.01-10 $\mu \mathrm{M})$, DPDPE $(10 \mu \mathrm{M})$ and $\mathrm{U}-69593(10 \mu \mathrm{M})$ were co-perfused with $\mathrm{KCl}(120 \mathrm{mM})$ during the second $\mathrm{KCl}$-perfusion period $\left(\mathrm{S}_{2}\right)$. Naltrexone $(3$ and $9 \mathrm{mg} / \mathrm{kg}$ ) was intraperitoneally (i.p.) injected $20 \mathrm{~min}$ before $S_{2}$ stimulation. $S_{2} / S_{1}$ was calculated to quantify the ratio of fractional NA release between the second $\left(S_{2}\right)$ and the first $\left(S_{1}\right)$ periods of $\mathrm{K}^{+}$stimulation. Each point represents the mean of 3-6 experiments. Vertical bars represent the S.E.M. ${ }^{*} P<0.05$ and ${ }^{* *} P$ $<0.01$ as compared with non-treated controls. ${ }^{\#} P<0.05$ as compared with morphine $(1 \mu \mathrm{M})$ treated rats.

dialysate collected before (Fig. 5B), after addition of $\mathrm{KCl}(120 \mathrm{mM})$ (Fig. 5C), and after the simultaneous addition of $\mathrm{KCl}$ and morphine $(1 \mu \mathrm{M})$ (Fig. 5D). At a concentration of $0.01,0.1$ and $1 \mu \mathrm{M}$, morphine produced dose-dependent decreases in NA release. It appeared to produce maximum decreases in NA release at a concentration of $1 \mu \mathrm{M}$ (Fig. 6). An agonist highly selective for $\delta$-opioid receptors, DPDPE, at the high concentration of $10 \mu \mathrm{M}$, caused no inhibition of NA release when co-perfused with $\mathrm{KCl}$ during $\mathrm{S}_{2}$. Similarly, U-69593, an agonist highly selective for $\kappa^{-}$ opioid receptors, caused no inhibition of NA release (Fig. 6). No significant differences in either basal NA levels or $\mathrm{K}^{+}$-evoked NA release during $\mathrm{S}_{1}$ were found between opioid agonist treated groups and non-treated controls (Table 1). When added without $\mathrm{KCl}$, none of the three opioid agonists affected the spontaneous release of NA.

3.5. Antagonism by naltrexone to the morphine $(1 \mu M)$ induced inhibition of $N A$ release

In order to further evaluate whether the inhibitory effects of morphine on NA release were mediated via $\mu$-opioid receptors, the action of morphine was examined in rats pretreated with naltrexone, a selective opioid antagonist for $\mu$-opioid receptors. Co-perfused morphine $(1 \mu \mathrm{M})$ after i.p. administration of naltrex-
Table 1

Basal noradrenaline (NA) levels and $\mathrm{K}^{+}(120 \mathrm{mM})$-evoked NA release from the rat hippocampus

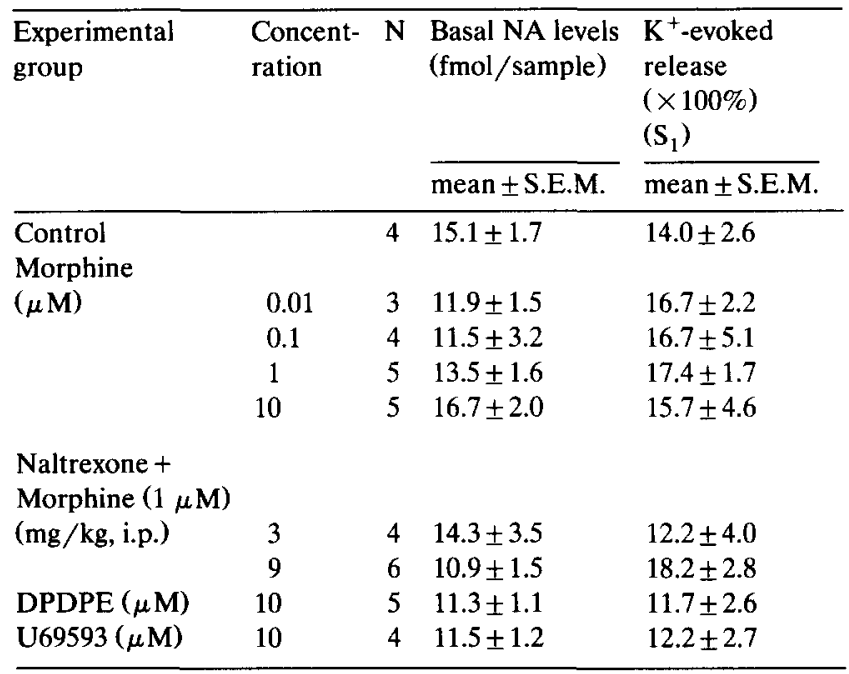

one $(3 \mathrm{mg} / \mathrm{kg}$ ) failed to significantly decrease the $\mathrm{K}^{+}$-evoked NA release. The morphine-induced inhibitory effects, on the other hand, were significantly abolished by $9 \mathrm{mg} / \mathrm{kg}$, i.p. of naltrexone (Fig. 6). Naltrexone by itself did not cause changes in the $\mathrm{K}^{+}$. evoked NA release or the spontaneous NA levels.

3.6. Effects of PTX treatment on the morphine $(1 \mu M)$ induced inhibition of $N A$ release

To evaluate whether the inhibitory effects of morphine on NA release requires the interaction between $\mu$-opioid receptors and PTX-sensitive G-proteins, experiments were carried out on the PTX treated hip-

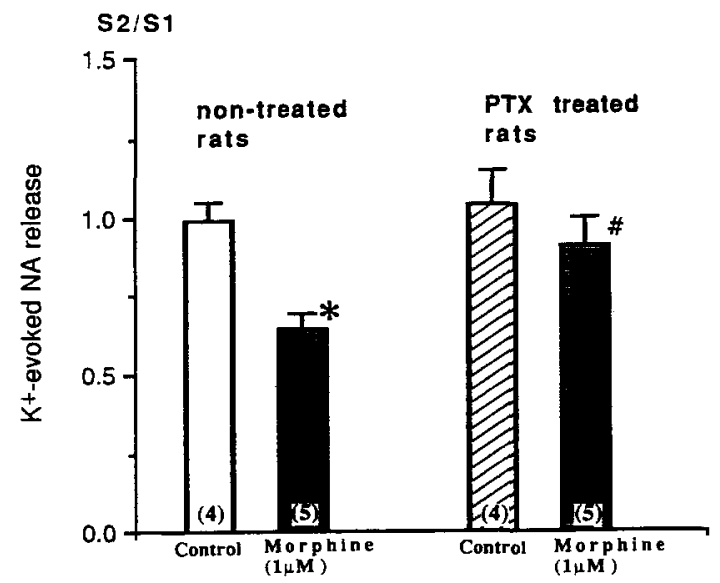

Fig. 7. Effects of PTX treatment on morphine $(1 \mu \mathrm{M})$-induced inhibitory action on noradrenaline (NA) release from the rat hippocampus. PTX $(1 \mu \mathrm{g} / \mathrm{ml})$ was perfused continuously $(7 \mu \mathrm{l} / \mathrm{min})$ into the hippocampus for $70 \mathrm{~min}$ by push-pull perfusion. Each point represents the mean of 4-5 experiments. Vertical bars represent the S.E.M. ${ }^{*} P<0.05$ as compared with non-treated controls. ${ }^{*} P<0.05$ as compared with morphine $(1 \mu \mathrm{M})$-treated rats. 
pocampus to inactivate G-proteins using a push-pull cannulation. In PTX treated control rats, the basal NA levels were $12.0 \pm 1.4 \mathrm{fmol} /$ sample and the $S_{2} / S_{1}$ ratio was $1.0 \pm 0.1(n=4)$. These values did not significantly differ from those of non-treated rats. In the morphine $(1 \mu \mathrm{M})$ co-perfused group of PTX treated rats, the basal NA levels were $12.5 \pm 1.5 \mathrm{fmol} /$ sample and the $S_{2} / S_{1}$ ratio of NA release was $0.9 \pm 0.1(n=5)$. PTX treatment significantly prevented the morphineinduced $(1 \mu \mathrm{M})$ decreases in $\mathrm{K}+$-evoked NA release (Fig. 7).

\section{Discussion}

In this study, we measured the endogenous NA release in the rat hippocampus and demonstrated that the functional modulation via the $\mu$-opioid receptors on NA release from the rat hippocampus exists in vivo.

The spontaneous NA release measured by use of brain microdialysis coupled with HPLC-ECD was suppressed by perfusion with TTX, while it was increased by the peripheral administration of desipramine. These findings indicate that the extracellular NA levels detected in the dialysate reflect the potential-induced NA release from the nerve terminals. Furthermore, the fact that the $\mathrm{K}^{+}$-evoked NA release was completely prevented by removal of $\mathrm{Ca}^{2+}$ from perfusion fluid showed that the $\mathrm{K}^{+}$-evoked NA release was regulated via a $\mathrm{Ca}^{2+}$-dependent mechanism. Taken together, these results clearly indicate that both the spontaneous and the $\mathrm{K}^{+}$-evoked NA release were of neuronal origin.

In the present study, the $\mathrm{K}^{+}$-evoked NA release from the hippocampus was significantly and concentration-dependently inhibited by co-perfused morphine. Neither the highly selective opioid receptor agonist for $\delta$-receptors, DPDPE nor that for $\kappa$-agonist, U-69593, however, affected the $\mathrm{K}^{+}$-evoked $\mathrm{NA}$ release. The morphine-induced inhibition of $\mathrm{K}^{+}$-evoked NA release was antagonized by selective $\mu$-opioid receptor antagonist, naltrexone. These results suggest that the opioid receptors involved in the inhibition of hippocampal NA release may be $\mu$-opioid receptors. These findings are in agreement with in vitro experiments that show that electrically stimulated or $\mathrm{K}^{+}$-evoked $\left[{ }^{3} \mathrm{H}\right] \mathrm{NE}$ overflow from hippocampus $[14,16]$, cerebral cortex $[2,10,21]$ and hypothalamus $[10,31]$ were inhibited by morphine and the selective $\mu$-opioid receptor agonist, [D-Ala ${ }^{2}, N$ methyl-Phe ${ }^{4}$, Gly ${ }^{5}$-ol] enkephalin (DAGO). However, Heijna et al. [11] reported that the $\left[{ }^{3} \mathrm{H}\right] \mathrm{NE}$ release from the rat mediobasal hypothalamus was not modulated by any of the opioid receptors, despite the immunocytochemical reports showing that the hypothalamus contains a large number of opioidergic neuron. They commented that opioid receptor-mediated $\left[{ }^{3} \mathrm{H}\right]$ $\mathrm{NE}$ release appears not to be a general phenomenon in the rat brain. Although we cannot offer a precise explanation for the difference between our data and their results, the discrepancy may be the result of regional distributions of noradrenergic nerve fibers or a difference in experimental conditions. On the other hand, in vitro studies have demonstrated a species difference with regard to the modulation of NA release via the opioid receptors. For instance, in the guinea pig hippocampus [33], electrically stimulated $\left[{ }^{3} \mathrm{H}\right] \mathrm{NA}$ release was inhibited by $\mu-, \delta$ and $\kappa$-opioid receptors, whereas in the rabbit hippocampus [14,16], $\kappa$-opioid receptors are predominantly involved in the inhibitory regulation of $\left[{ }^{3} \mathrm{H}\right] \mathrm{NA}$ release. The present findings leave little doubt that the NA release, at least in the rat hippocampus, is regulated by $\mu$-opioid receptors.

It was not possible to demonstrate a tonic inhibitory action of endogenous opioid receptors on hippocampal NA release in this experiment because neither morphine nor naltrexone affect the spontaneous NA release when given alone. Although several investigators have reported that the peripheral administration of morphine changed the NA turnover in the rat brain, opposite results have been obtained through the use of different brain areas or experimental conditions. For instance, acutely and chronically administered morphine increased the NA turnover in the rat brainstem and cortex $[27,28,30]$. Bilateral injection of morphine into the rat periaqueductal gray also increased the cerebral NA turnover [26]. In contrast, Gabriel et al. [8] have shown that chronically administered morphine decreased NA levels in the rat mediobasal hypothalamus, while it did not alter the NA turnover in the preoptic area-anterior hypothalamus. In this experiment, we observed that an acute injection of morphine (5 and $10 \mathrm{mg} / \mathrm{kg}$, i.p.) gradually and dose-dependently increased the spontaneous NA levels in the rat hippocampus (data not shown). We can not explain the reasons for the various effects of peripherally administered morphine on the noradrenergic neurons, but there might be an indirect action due to disinhibitory action of morphine, i.e., the inhibition of the release of inhibitory transmitters such as GABA [35].

The neuronal mechanisms of the opioid receptors have not yet been established. Luján et al. [18] reported that the administration of PTX blocked the ability of morphine to inhibit electrically stimulated contractions in the guinea pig isolated ileum. Morphine [23]- and opioids [24]-induced antinociceptive actions were abolished by the pretreatment with PTX. These reports suggest that the opioid receptor-elicited responses are mediated by G-proteins. However, Amerini et al. [1] showed that the pretreatment with PTX did not prevent the inhibitory regulation of the efferent function of the sensory neurones by opioid receptor stimulation. In this experiment, we observed that PTX locally perfused into the hippocampus using 
push-pull cannulation significantly prevented the morphine-induced inhibitory effect on NA release. These findings suggest the possibility that $\mu$-opioid receptors, at least in the rat hippocampus, require intact G-proteins which are substrates of PTX.

In summary, the $\mathrm{K}^{+}$-evoked $\mathrm{NA}$ release from the hippocampus of freely moving rats was inhibited by morphine added to the perfusion fluid. This morphineinduced inhibitory effect was antagonized by naltrexone. These findings suggest that opioid receptor regulated NA release in the rat hippocampus may belong to the $\mu$-opioid receptors which are located on the noradrenergic nerve terminals. Furthermore, the fact that PTX treatment abolished the morphine-induced inhibitory effects suggests the possibility that the modulation of $\mu$-opioid receptors on the noradrenergic neurons might be linked to G-proteins. In other words, the modulation of the $\mu$-opioid receptors on the noradrenergic neurons might play a functional role in vivo.

Acknowledgements. These studies were conducted in accordance with the standards established by the Guide for the Care and Use of Laboratory Animals of the Hokkaido University School of Medicine.

\section{References}

[1] Amerini, S., Rubino, A., Mantelli, L., Filippi, S. and Ledda, F., The inhibitory effect of opioid and $\alpha_{2}$-adrenoceptor agonists on cardiac sensoty neurones is pertussis toxin-insensitive, Eur. $J$. Pharamacol, 216 (1992) 445-448.

[2] Arbilla, S. and Langer, S.Z., Morphine and beta endorphin inhibit release of noradrenaline from cerebral cortex but not of dopamine from rat striatum, Nature, 271 (1978) 559-561.

[3] Attila, L.M.J. and Ahtee, L., Acceleration of cerebral noradrenaline turnover after morphine withdrawal and its retardation by acute morphine administration in rats, Naunyn-Schmiedeberg's Arch. Pharmacol, 327 (1984) 193-200.

[4] Badoer, E., Würth, H., Türck, D., Qadri, F., Itori, K., Dominiak, $P$. and Unger, $\mathrm{T}$., The $\mathrm{K}^{+}$-induced increases in noradrenaline and dopamine release are accompanied by reductions in the release of their intraneuronal metabolites from the rat anterior hypothalamus, Naunyn-Schmiedeberg's Arch. Pharmacol., 339 (1989) 54-49.

[5] Cenci, M.A., Kalén, P., Mandel, R.J. and Björklund, A., Regional differences in the regulation of dopamine and noradrenaline release in medial frontal cortex, nucleus accumbens and caudate-putamen: a microdialysis study in the rat, Brain Res., 581 (1992) 217-228.

[6] Crain, B.J., Chang, K.J. and McNamara, J.O., Quantitative autoradiographic analysis of mu and delta opioid binding sites in the rat hippocampal formation, J. Comp. Neurol., 246 (1986) $170-180$.

[7] Done, C., Silverstone, P. and Sharp, T., Effect of naloxone-precipitated morphine withdrawal on noradrenaline release in rat hippocampus in vivo, Eur. J. Pharmacol., 215 (1992) 333-336.

[8] Gabriel, S.M., Clark, J.T., Kalra, P.S., Kalra, S.P. and Simpkins, J.W., Chronic morphine and testosterone treatment: effects on norepinephrine and serotonin metabolism and gonadotropin secretion in male rats, Brain Res., 447 (1988) 200-203.
[9] Gomes, C., Svensson, T.H. and Trolin, G., Effects of morphine on central catecholamine turnover, blood pressure and heart rate in the rat, Naunyn-Schmiedeberg's Arch. Pharmacol., 294 (1976) 141-147.

[10] Gothert, M., $\mathrm{Ca}^{2+}$-induced noradrenaline release from central noradrenergic neurons promoted by high $\mathrm{K}^{+}$concentration or ionophore A23187, Nauny-Schmiedeberg's Arch. Pharmacol., 307 (1979) 29-37.

[11] Heijna, M.H., Padt, M., Hogenboon, F., Schoffelmeer, A.N.M. and Mulder, A.H., Opioid-receptor-mediated inhibition of $\left[{ }^{3} \mathrm{H}\right]$ dopamine but not $\left[{ }^{3} \mathrm{H}\right]$ noradrenaline release from rat mediobasal hyopothalamus slices, Neuroendocrinology, 54 (1991) $118-126$.

[12] Itoh, Y., Oishi, R., Nishibori, M. and Saeki, K., In vivo measurement of noradrenaline and 3,4-dihydroxyphenylethyleneglycol in the rat hypothalamus by microdialysis: effects of various drugs affecting noradrenaline metabolism, J. Pharmacol. Exp. Ther., 225 (1990) 1090-1097.

[13] Jackisch, R., Geppert, M., Brenner, A.A. and Illes, P., Presynaptic opioid receptors modulating acetylcholine release in the hippocampus of the rabbit, Naunyn-Schmiedeberg's Arch. Pharmacol., 332 (1986) 156-162.

[14] Jackisch, R., Geppert, M. and Illes, P., Characterization of opioid receptors modulating noradrenaline release in the hippocampus of the rabbit, J. Neurochem., 46 (1986) 1802-1810.

[15] Kalén, P., Kokaia, M., Lindvall, $O$. and Björklund, A., Basic characteristics of noradrenaline release in the hippocampus of intact and 6-hydroxydopamine-lesioned rats as studied by in vivo microdialysis, Brain Res., 474 (1988) 374-379.

[16] Leslie, F.M., Methods used for the study of opioid receptors, Pharmacol. Rev, 39 (1987) 197-249.

[17] L'Heureux, R., Dennis, T., Curet, O. and Scatton, B., Measurement of endogenous noradrenealine release in the rat cerebral cortex in vivo by transcortical dialysis: effects of drugs affecting noradrenergic transmission, J. Neurochem., 46 (1986) 1794-1801.

[18] Luján, M., López, E., Ramírez, R., Aguila, H., MartínezOimedo, M.A. and Garcia-Sainz, J.A., Pertussis toxin blockds the action of morphine, norepinephrine and clonidine on isolated guinea-pig ileum, Eur. J. Pharmacol., 100 (1984) 377-384.

[19] Mansour, A., Khachaturian, H., Lewis, M.E., Akil, H. and Watson, S.J., Autoradiographic differentiation of mu, delta and kappa opioid receptors in the rat forebrain and midbrain, $J$. Neurosci., 7 (1987) 2445-2464.

[20] Mulder, A.H., Wardeh, G., Hogenboom, F. and Frankhuyzen, A.L. $\kappa$ - and $\delta$-Opioid receptor agonists differentially inhibit striatal dopamine and acetylcholine release, Nature, 308 (1984) 278-280.

[21] Mulder, A.H., Hogenboom, F., Wardeh, G. and Schoffelmeer, A.N.M., Morphine and enkephalins potently inhibit $\left[{ }^{3} \mathrm{H}\right]$ noradrenaline release from rat brain cortex synaptosomes: further evidence for a presynaptic localization of $\mu$-opioid receptors, $J$. Neurochem., 48 (1987) 1043-1047.

[22] Mulder, A.H., Burger, D.M., Wardeh, G., Hogenboon, F. and Frankhuyzen, A.L., Pharmacological profile of various $\kappa$-agonists at $\kappa-, \mu$-and $\delta$-opioid receptors mediating presynaptic inhibition of neurotransmitter release in the rat brain, $B r . J$. Pharmacol., 102 (1991) 518-522.

[23] Parenti, M., Tirone, F., Giagnoni, G., Recora, N. and Parolaro D., Pertussis toxin inhibits the antinociceptive action of morphine in the rat, Eur. J. Pharmacol., 124 (1986) 357-359.

[24] Przewlocki, R., Costa, T., Lang, J. and Herz, A., Pertussis toxin abolishes the antinociception mediated by opioid receptors in rat spinal cord, Eur. J. Pharmacol., 144 (1987) 91-95.

[25] Rasmussen, K., Beitner-Johnson, D.B., Krystal, J.H., Aghajanian, G.K. and Nestler, E.J., Opiate withdrawal and the rat locus coeruleus: behavioural, electrophysiological, and biochemical correlates, J. Neurosci., 10 (1990) 2308-2317. 
[26] Reigle T.G., Increased brain norepinephrine metabolism correlated with analgesia produced by the periaqueductal gray injection of opiates, Brain Res., 338 (1985) 155-159.

[27] Roffman, M., Cassens, G. and Schildkraut, J.J., The effects of acute and chronic administration of morphine on norepinephrine turnover in rat brain regions, Biochem. Pharmacol., 26 (1977) 2355-2358.

[28] Roth, K.A., Mefford, I.M. and Barchas, J.D., Epinephrine, norepinephrine, dopamine and serotonin: differential effects of acute and chronic stress on regional brain amines, Brain Res., 239 (1982) 417-424.

[29] Stinus, L., Moal, M. Le and Koob, G.F., Nucleus accumbens and amygdala are possible substrates for the aversive stimulus effects of opiate withdrawal, Neuroscience, 37 (1990) 767-773.

[30] Sugrue, M.F., The effects of acutely administered analgesics on the turnover of noradrenaline and dopamine in various regions of the rat brain, Br. J. Pharmacol., 52 (1974) 159-165.

[31] Taube, H., Starke, D. and Borowski, E., Presynaptic receptor systems on the noradrenergic neurones of rat brain, NaunySchmiedeberg's Arch. Pharmacol., 229 (1977) 123-141.

[32] Taylor, J.R., Elsworth, J.D., Garcia, E.J. Grant, S.J., Roth, R.H. and Redmond, D.E., Clonidine infusion into the locus coeruleus attenuates behavioural and neurochemical changes associated with naloxone precipitated withdrawal, Psychopharmacology, 96 (1988) 121-134.

[33] Werling, L.L., Brown, S.R. and Cox, B.M., Opioid receptor regulation of the release of norepinephrine in brain, Neuropharmacology, 26 (1987) 987-996.

[34] Yoshioka, M., Matsumoto, M., Togashi, H., Smith, C.B. and Saito, H., Opioid receptor regulation of 5-hydroxytryptamine release from the rat hippocampus measured by in vivo microdialysis, Brain Res., 613 (1993) 74-79.

[35] Zieglgänsberger, W., French, E.D., Siggins, G.R. and Bloom, F.E., Opioid peptides may excite hippocampal pyramidal neurons by inhibiting adjacent inhibitory interneurons, Science, 205 (1979) $415-417$ 